\title{
Analisis Hukum Islam tentang Pendistribusian Zakat Fitrah oleh Takmir Masjid At-Taqwa terhadap Gharim yang Hutangnya untuk Lembaga
}

\author{
A. Saiful Aziz, Subhan, ${ }^{\circledR}$ Ubbadul Adzkiya' \\ Universitas Wahid Hasyim Semarang \\ jhonsaifulaziz@gmail.com, subhanzein100@gmail.com, ${ }^{\circledR}$ adzkiya@unwahas.ac.id
}

\begin{abstract}
This study describes how the implementation of zakat fitrah management at the At-Taqwa Mosque, Pamedaran Village, Brebes Town, and to find out the analysis of Islamic law on the distribution of zakat fitrah to people who have debts to institutions. This research was conducted with a qualitative method and a descriptive approach. The conclusion of the study shows: (1) Management of zakat fitrah at the At-Taqwa Mosque begins with planning through deliberations of leaders and amil on D3 Eid al-Fitr and carried out on D-1 Eid al-Fitr with the time of collecting zakat fitrah from after dawn prayer until before prayer Asr, then the amil calculates the amount of zakat fitrah that has been collected, then distributes it to asnaf in the At-Taqwa Mosque environment, namely asnaf indigent, poor, amil, fisabilillah and gharim. (2) The distribution of zakat fitrah carried out by the takmir of the At-Taqwa Mosque in Pamedaran Village to gharim whose debts to institutions are not in accordance with Islamic law, because what is meant by gharim according to the four schools of thought is a person who is in debt and it is an obligation for him to pay the debt, while in this case the person who is considered a gharim is only an intermediary for the debt and the real owner of the debt is the institution/mosque.
\end{abstract}

Keywords: Islamic Law, Zakat Fitrah, Distribution of Zakat, Gharim.

\section{Abstrak}

Penelitian ini mendeskripsikan bagaimana pelaksanaan pengelolaan zakat fitrah di Masjid AtTaqwa Desa Pamedaran Kecamatan Ketanggungan Kabupaten Brebes, dan untuk mengetahui analisis hukum Islam terhadap pendistribusian zakat fitrah kepada orang yang mempunyai hutang untuk lembaga. Penelitian ini dilakukan dengan metode kualitatif dan pendekatan deskriptif. Kesimpulan penelitian menunjukan: (1) Pengelolaan zakat fitrah di Masjid At-Taqwa diawali dengan perencanaan melalui musyawarah para tokoh dan amil pada H-3 idul fitri dan dilaksanakan pada H-1 idul fitri dengan waktu pengumpulan zakat fitrah dari setelah sholat subuh sampai menjelang sholat ashar, lalu amil menghitung jumlah zakat fitrah yang sudah terkumpul, kemudian didistribusikan kepada asnaf yang ada di lingkungan Masjid At-Taqwa yaitu asnaf fakir, miskin, amil, fisabilillah dan gharim. (2) Pendistribusian zakat fitrah yang dilakukan oleh Takmir Masjid AtTaqwa Desa Pamedaran terhadap gharim yang hutangnya untuk lembaga tidak sesuai dengan hukum Islam, karena yang dimaksud gharim menurut empat madzhab adalah orang yang berhutang dan menjadi kewajiban bagi dirinya untuk membayar hutang tersebut, sedangkan dalam hal ini orang yang dianggap sebagai gharim hanya sebatas perantara atas hutang itu dan pemilik hutang yang sesungguhnya adalah lembaga/masjid tersebut.

Kata Kunci : Hukum Islam, Zakat Fitrah, Distribusi Zakat, Gharim 


\section{Pendahuluan}

Pengelolaan zakat yang maksimal dapat dijadikan sumber kekayaan yang diharapkan bisa memberikan manfaat untuk meningkatkan kesejahteraan bagi seluruh umat Islam. Selain itu, dengan pengelolaan zakat yang baik diharapkan dapat membangun kesadaran para muzakki untuk melaksanakan kewajibannya dalam rangka mensucikan diri, membersihkan harta dan mendapatkan ridha Allah SWT. Sebagai masyarakat muslim, di Desa Pamedaran tidak terlepas dari aturan dan norma agama Islam yang memegang tinggi prinsip solidaritas, hal itu dapat dibuktikan dengan melihat konsep yang berlaku di Desa Pamedaran, yaitu saling menghargai, menghormati dan saling tolong menolong.

Untuk sementara, pengamatan yang dilakukan oleh penulis pada tanggal 10 agustus 2020, pukul 17:00 melalui wawancara dengan bapak Badruddin sebagai amil zakat fitrah, beliau mengatakan: "pelaksanaan zakat fitrah di Desa Pamedaran setiap tahun masyarakat mempercayakan zakatnya kepada takmir Masjid yang mana dalam pendistribusiannya berdasarkan pemetaan ekonomi dan sosial" ${ }^{11}$ Akan tetapi hal itu dirasa kurang tepat, dikarenakan takmir masjid (Amil zakat) beranggapan bahwa mayoritas masyarakatnya berkedudukan sama rata dan hanya segelintir orang yang dianggap berkekurangan dalam sudut pandang ekonominya, serta tidak adanya pencatatan resmi atau daftar orang yang dikeluarkan pihak berwenang tentang kriteria yang cocok dengan delapan asnaf, sehingga ada kerancuan untuk menggolongkannya kedalam mustahiq zakat. Tentu hal ini akan berdampak pada hasil dan kemajuan yang diperoleh dari zakat setiap tahunnya tidak terlihat, apakah mustahiq berkurang atau bertambah, dan apakah semua zakat fitrah sudah terdistribusikan kepada mustahiqnya.

Sebagaimana hasil dari pengamatan tersebut, bahwa yang terjadi dalam pendistribusian zakat fitrah di Desa Pamedaran, "orang yang ekonominya dalam keadaan berkecukupan namun mempunyai utang untuk suatu lembaga dengan atas nama orang tersebut (bukan utang pribadi) itu dianggap sebagai orang yang boleh mendapat bagian dari zakat, berdasarkan anggapan bahwa orang tersebut rmasuk kedalam asnaf gharim". Berdasarkan hal tersebut, maka penting adanya kejelasan tentang kriteria gharim yang berhak menerima zakat, serta perlunya ada pencatatan

\footnotetext{
${ }^{1}$ Badruddin, Amil Zakat Fitrah, Wawancara pada 10 Agustus 2020, Pukul 17:00 WIB
} 
resmi terkait daftar orang yang dikeluarkan pihak berwenang tentang kriteria yang cocok dengan delapan asnaf, agar zakat dapat disalurkan dengan tepat sasaran.

\section{Landasan Teori}

Menurut bahasa, zakat berasal dari kata zaka - yazku - zaka-an atau zakiya yazka - zakan yang berarti suci, bersih, tumbuh, berkembang, bertambah, dan berkah, namun sering diartikan menyucikan atau membersihkan. ${ }^{2}$ Sedangkan kata fitrah dari segi bahasa bermaksud futhur (berbuka puasa), fitrah (suci, bersih) dan fitri (fitrah semula jadi yang bersih). ${ }^{3}$ Secara istilah, zakat fitrah yaitu zakat yang dikeluarkan berdasarkan jumlah atau anggota keluarga, perempuan dan laki-laki, kecil maupun dewasa wajib mengeluarkan zakat fitrah pada bulan ramadlan. ${ }^{4}$

Selain itu zakat fitrah juga bisa disebut sebagai zakat nafs, yang berarti zakat untuk mensucikan jiwa diujung bulan Ramadlan dengan mengeluarkan sebagian bahan makanan pokok yang dapat mengenyangkan menurut ukuran tertentu sebagaimana yang diatur oleh syari'at sebagai tanda berakhirnya bulan Ramadlan dan pembersih dari hal-hal yang mengotori ibadah puasa (masih adanya rasa dengki, marah, berkata sia-sia dan lain sebagainya). ${ }^{5}$ Orang yang berhak mendapatkan zakat fitrah yaitu sama dengan orang yang berhak mendapatkan zakat lain pada umumnya, seperti yang telah dijelaskan dalam firman Allah SWT. Q.S AtTaubah ayat 60 .

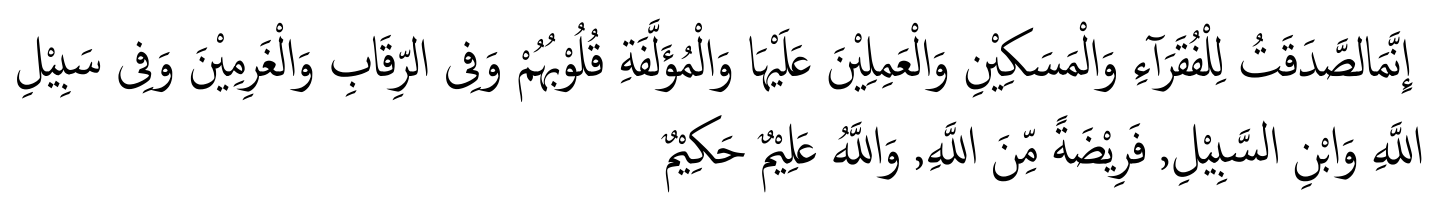

Received: 2021-11-19 Accepted: 2021-12-21

Artinya: sesungguhnya zakat-zakat itu hanyalah untuk orang fakir, orang-orang Published: 2021-12-23 miskin, pengurus-pengurus zakat, para muallaf yang dibujuk hatinya untuk memerdekakan budak, orang-orang yang berhutang untuk jalan Allah, sebagai

\footnotetext{
${ }^{2}$ Al-Furqon Hasbi, 125 Masalah Zakat, Solo: Tiga Serangkai, 2008, hlm.13

${ }^{3}$ Shofian Ahmad, Amir Husin Mohd. Nor, Zakat Membangun Ummah, Kuala Lumpur: Sanon Printing Corporation SDN BHD, 2002, hlm.32.

${ }^{4}$ Qodariah Barkah, Peny Cahaya Azwari, Saprida, Zuul Fitriani Umari, Fikih Zakat, Sedekah, dan Wakaf, Jakarta: Prenadamedia Group, 2020, hlm.53

${ }^{5}$ Putra Julkipli, Pelaksanaan Distribusi Zakat Fitrah Di Kelurahan Bintuju Kecamatan Batang Angkola Kabupaten Tapanuli Selatan, (Skripsi), Padangsidimpuan: Jurusan Ahwal Al-Syakhsiyyah Fakultas Syariah Dan Ilmu Hukum Institut Agama Islam Negeri Padangsidimpuan, 2018, hlm.13-15
} 
sesuatu ketetapan yang diwajibkan Allah, dan Allah maha mengetahui lagi maha bijaksana. $^{6}$

Berdasarkan ayat diatas, golongan orang-orang yang berhak menerima zakat diantaranya adalah sebagai berikut: a) Faqir, Imam Abu Hanifah berpendapat orang fakir adalah orang yang tidak memiliki penghasilan tetap untuk memenuhi kebutuhan hidup sehari-hari. Adapun menurut jumhur ulama fakir adalah orangorang yang tidak mempunyai harta atau penghasilan layak untuk memenuhi kebutuhan sandang, pangan, tempat tinggal, dan segala keperluan pokok lainnya, baik untuk dirinya sendiri maupun untuk keluarga dan orang-orang yang menjadi tanggungannya. ${ }^{7}$ b) Miskin, Menurut Imam Abu Hanifah, orang miskin adalah orang yang memiliki pekerjaan tetap tetapi tiddak dapat mencukupi kebutuhannya seharihari. Jumhur ulama mengatakan bahwa orang miskin adalah orang yang mempunyai harta atau penghasilan layak untuk memenuhi kebutuhan diri dan tanggungannya, tetapi penghasilan tersebut tidak mencukupi. Akan tetapi Imam Abu Yusuf dan Ibnu Qasim (tokoh fiqih Mazhab Maliki) tidak membedakan secara defenitif kedua kelompok orang tersebut (fakir dan miskin). Menurut mereka, fakir dan miskin adalah dua istilah yang mengandung pengertian yang sama. ${ }^{8}$ c) Amil, Amil zakat adalah seseorang atau sekelompok orang yang diangkat oleh pemerintah untuk mengelola pelaksanaan ibadah zakat atau seseorang/sekelompok orang yang dibentuk oleh masyarakat dan disahkan oleh pemerintah untuk mengelola pelaksanaan ibadah zakat. ${ }^{9}$ d) Muallaf, adalah orang yang dilunakkan hatinya agar mereka tertarik pada agama Islam karena keimanan mereka belum mantap, atau untuk menghindari petaka yang mungkin mereka lakukan terhadap kaum Muslimin, atau mengambil keuntungan yang mungkin dimanfaatkan untuk kepentingan mereka. ${ }^{10}$ e) Riqab, adalah para budak yang dimaksudkan disini, menurut jumhur ulama ialah para budak muslim yang telah membuat perjanjian dengan tuannya

${ }^{6}$ Kementerian Agama RI, Al-Qur'an, hlm. 137.

${ }^{7}$ Andi Suryadi, Mustahiq dan Harta Yang Wajib Dizakati Menurut Kajian Para Ulama, Jurnal Keislaman, Kemasyarakatan \& Kebudayaan, Program Pascasarjana Uin Sultan Maulana Hasanuddin Banten, Volume 19, (1), 2018, hlm .3.

8 lbid, hlm. 3

${ }^{9}$ Ahmad Satori Ismail, Fikih Zakat Kontekstual Indonesia, Jakarta: Badan Amil Zakat Nasional, 2018. hlm. 272.

10 Khairul Amru Harahap dan Masrukhin, Fikih Sunnah, (Terjemah), Jakarta: Cakrawala Publishing, 2015. hlm. 145 
(almukatabun) untuk dimerdekakan dan tidak memiliki uang untuk membayar tebusan atas diri mereka, meskipun mereka telah bekerja keras membanting tulang mati-matian. ${ }^{11}$ f) Gharim, adalah orang yang berhutang untuk dirinya sendiri dan bukan untuk maksiat. Maka gharim boleh diberi bagian zakat jika tidak mampu melunasi utangnya, sekalipun rajin bekerja, sebab pekerjaan itu tidak bisa menutup kebutuhannya untuk melunasi hutang bila telah tiba saat pembayarannya. ${ }^{12} \mathrm{~g}$ ) $\mathrm{Fi}$ Sabilillah, yaitu orang yang ilmu maupun perbuatannya dapat menyampaikan kepada keridhaan Allah SWT. Sedangkan mayoritas ulama berpendapat bahwa yang dimaksud sabilillah adalah berperang. ${ }^{13}$ h) Ibnu Sabil/Musafir, yaitu orang yang bepergian (Musafir) untuk pekerjaan yang baik (tha'ah) bukan untuk maksiat. Jika dia tidak dibantu, diperkirakan dia tidak akan mencapai maksud dan tujuannya. Hal-hal yang termasuk perbuatan baik (tha'ah) diantaranya ibadah haji, berperang di jalan Allah, dan ziarah yang dianjurkan. ${ }^{14}$

Menurut madzhab Maliki gharim adalah seseorang yang mempunyai hutang, dan dia tidak memiliki apa-apa untuk membayar hutangnya. Meskipun dia sudah wafat, maka hutangnya itu dapat dilunasi dari zakat. ${ }^{15}$ Menurut madzhab Hanafi, gharim adalah seseorang yang berhutang dan tidak memiliki harta lebih selain untuk membayar hutangnya, membayar zakat kepadanya (untuk menutupi hutang) lebih penting daripada memberikan kepada fakir. ${ }^{16}$ Menurut Madzhab Hambali Kata gharimin merupakan bentuk jamak dari gharim yang artinya wajib karena hutang harus dibayar. ${ }^{17}$ 1) Seseorang yang mempunyai hutang untuk kepentingan pribadi, untuk hal-hal yang diperbolehkan atau yang diharamkan dalam agama dengan syarat ia sudah bertaubat, maka ia boleh menerima zakat hanya untuk menutupi sisa

11 Wahbah Al-Zuhayly, Zakat Kajian Berbagai Mazhab, Agus Effendi, Bahrudin Fananny (Penterjemah), Bandung: PT. Remaja Rosdakarya Offset, 2008, hlm. 285.

${ }^{12}$ M. Fikril Hakim, Abu Sholahuddin (Penterjemah), Fiqh Populer Terjemah Fathul Mu'in, Kediri: Lirboyo Press. hlm. 26.

${ }^{13}$ Lahmudin Nasution, Fiqih, Jakarta: Logos, 2015, hlm. 180.

${ }^{14}$ Wahbah Al-Zuhayly, Zakat Kajian Berbagai Mazhab, Agus Effendi, Bahrudin Fananny (Penterjemah), Bandung: PT. Remaja Rosdakarya Offset, 2008, hlm. 289.

${ }^{15}$ M. Zuhri dkk, Fiqih Empat Madzhab, Semarang: Asy-Syifa, 1994, Jilid 4, hlm. 164.

${ }^{16} \mathrm{Ibid}, \mathrm{hlm} .158$.

${ }^{17}$ Anshari Taslim, Fikih Imam Syafi'i, Puasa dan Zakat, (Terjemah), Jakarta: Pustaka Azzam, 2003, hlm. 205. 
hutangnya; 2) Orang yang mempunyai hutang untuk kepentingan sosial. ${ }^{18}$ Sedangkan gharim menurut madzhab Syafi'i adalah terdiri dari empat macam, ${ }^{19}$ diantaranya yaitu: 1) Mereka yang mempunyai hutang karena mendamaikan kedua kelompok yang bersengketa untuk menghindari pertempuran yang mengarah pada pembunuhan, maka golongan ini berhak mendapatkan zakat meskipun penerimanya merupakan orang kaya; 2) Orang yang mempunyai hutang karena menjamin seseorang; 3) Orang yang mempunyai hutang untuk kepentingan dirinya atau keluarganya dalam hal yang diperbolehkan; 4) Orang yang mempunyai hutang untuk kesejahteraan umum seperti membangun rumah persinggahan untuk menjamu tamu, membangun masjid atau rumah sakit dan lain sebagainya. Jika tidak mampu membayarnya maka mereka berhak mendapatkan zakat.

Yusuf Al-Qardhawy berpendapat bahwa kriteria gharim yang berhak menerima zakat ada dua macam, yaitu: ${ }^{20} 1$ ) Orang yang mempunyai hutang untuk kepentingannya sendiri, seperti untuk memberi nafkah, membeli pakaian, melaksanakan pernikahan, mengobati orang sakit, menikahkan anak, membangun rumah, atau menggantiakan barang orang lain yang rusak. Termasuk kriteria gharim disini yaitu mereka yang tertimpa bencana secara tiba-tiba seperti kebakaran, banjir, gempa bumi ataupun yang lainnya. Baik itu terjadi pada dirinya sendiri ataupun pada hartanya sehingga ia meminjam bagi dirinya dan keluarganya dikarenakan mempunyai kebutuhan yang mendesak; 2) Seseorang yang memiliki nilai kemanusiaan dan keluhuran yang tinggi, atau cita-cita luhur yang dikenal luas dalam masyarakat arab dan Muslim. Misalnya, seseorang yang mempunyai hutang karena mendamaikan dua kubu yang bersengketa dalam rebutan harta dan dengan sukarela ia menggantikan harta yang dipersengketakan agar tidak menimbulkan kemadharatan, orang yang melakukan kegiatan sosial yang bermanfaat seperti membangun panti asuhan, membangun rumah sakit, membangun masjid untuk ibadah shalat ataupun perbuatan baik lainnya yang ditujukan untuk melayani kepentingan masyarakat. Sesungguhnya orang tersebut telah berkhidmat didalam kebajikan untuk kepentingan masyarakat. Arti semua ini adalah bahwa seseorang

\footnotetext{
${ }^{18}$ Moch. Anwar, dkk, Fathul Mu'in, (Terjemah), Bandung: Sinar Baru Agensindo, 1994, hlm. 583.

${ }^{19}$ Anshari Taslim, hlm 205

${ }^{20}$ Didin Hafidhuddin, Hukum Zakat, Terj. Jakarta: PT .Pustaka Mizan, 1999. hlm. 604
} 
yang mempunyai hutang karena untuk melayani kepentingan masyarakat, meskipun dia orang kaya hendaknya diberi bagian zakat untuk membayar hutangnya.

\section{Metode Penelitian}

Langkah-langkah yang peneliti gunakan untuk menyelesaikan penelitian ini jika dilihat dari objeknya, penelitian ini termasuk jenis penelitian lapangan atau field research, yaitu dengan mencari data secara langsung ke lapangan dengan melihat lebih dekat obyek yang akan diteliti. Berdasarkan pendekatannya, penelitian ini termasuk penelitian kualitatif, yaitu penelitian yang mendapatkan data deskriptif berbentuk kata-kata tertulis dari orang-orang atau pelaku yang bisa diamati. Data yang dipakai pada penelitian ini didapat melalui studi lapangan (field research), dengan teknik observasi, wawancara, mengumpulkan dan mencatat berbagai data informasi yang didapatkan di lapangan.

\section{Hasil Penelitian dan Pembahasan}

Dalam ajaran agama Islam tidak hanya diwajibkan untuk membayar zakat saja, namun dalam penyalurannya juga diwajibkan agar tepat sasaran terhadap orang-orang yang berhak menerimanya. Oleh karena itu, negara telah mengatur segala sesuatu yang berkaitan dengan kegiatan pengelolaan zakat dalam undangundang Nomor 23 tahun 2011, yaitu meliputi perencanaan, pelaksanaan, pendistribusian dan pendayagunaan zakat (pasal 1 ayat 1 ). ${ }^{21}$ Begitupun pengelolaan zakat fitrah di Masjid At-Taqwa Desa Pamedaran sudah sesuai dengan ketentuan pengelolaan zakat berdasarkan pasal 1 ayat 1 , yakni perencanaan dilaksanakan pada H-3 hari Raya Idul Fitri, dengan diadakannya musyawarah para tokoh dan amil guna membahas untuk menentukan tugas masing-masing amil, yaitu ada yang bagian menerima zakat fitrah sekaligus memimpin niat zakat fitrah terhadap muzakki, bagian mencatat muzakki yang membayar zakatnya di masjid At-Taqwa, dan bagian menimbang kembali beras yang diserahkan oleh muzkki. Selain itu juga kegunaan daripada musyawarah yaitu untuk menentukan golongan orang-orang yang nantinya akan diberi zakat fitrah.

\footnotetext{
${ }^{21}$ Undang-Undang Republik Indonesia Nomor 23 Tahun 2011 Tentang Pengelolaan Zakat.
} Pasal 1 
Adapun pelaksanaannya yaitu pada $\mathrm{H}-1$ hari Raya Idul Fitri, dengan cara gotong royong dan dipusatkan di masjid yang terdapat di lingkungan masingmasing jama'ah. Para amil berkumpul di masjid dan masyarakat akan berbondongbondong datang ke masjid untuk membayarkan zakat fitrahnya, lalu para amil menerimanya dengan ditimbang ulang terlebih dahulu guna menyesuaikan timbangan yang sudah ditentukan yaitu 2,5 kilogram beras. Waktu pengumpulannya dilakukan dari pagi setelah waktu subuh sampai siang menjelang waktu shalat ashar, setelah beras terkumpul semuanya, lalu para amil menghitung jumlah seluruh hasil zakat fitrah dan menentukan bagian untuk masing-masing penerimanya. Untuk pedistribusiannya dilakukan dari mulai setelah shalat ashar sampai menjelang masuknya waktu shalat magrib, lalu para amil membagikannya kepada mustahiq zakat yang sudah ditentukan pada waktu musyawarah bersama para tokoh.

Dari hasil observasi dan wawancara dengan Tokoh Agama, amil, dan masyarakat jama'ah Masjid At-Taqwa Desa Pamedaran mengenai mekanisme pendistribusian zakat fitrah Peneliti mendapat gambaran yang cukup jelas, dimana dalam menentukan mustahiqnya melalui hasil musyawarah bersama para tokoh, termasuk dalam menentukan seseorang yang dianggap sebagai gharim. Dalam mendistribusikannya para amil memberikan kepda lima golongan, yaitu fakir, miskin, fisabilillah, amil dan gharim. Untuk mempermudah dan mewujudkan asas keadilan dalam Pendistribusian zakat fitrah yang dilaksanakan oleh amil di Masjid At-Taqwa Desa Pamedaran maka amil membagikannya disesuaikan dengan kedaan masingmasing jiwa penerimanya, dalam artian disesuaikan dengan kebutuhannya masingmasing. Sehingga dalam menentukan banyaknya bagian zakat fitrah yaitu dengan melihat kedudukan bahwa golongan orang fakir lebih rendah daripada orang miskin, maka jumlah bagiannya juga lebih banyak untuk golongan orang fakir dibandingkan dengan orang miskin. Sedangkan dalam menentukan bagian amil biasanya amil hanya mendapatkan bagian sesuai dengan upah kerja satu hari yaitu jumlah beras senilai uang $\mathrm{Rp}$ 80.000, begitupun untuk bagian fisabilillah, para amil biasanya menyamakan dengan bagian orang miskin, jika semua fakir miskin, fisabilillah dan amil sudah mendapatkan bagiannya lalu sisanya diberikan kepada gharim seluruhnya, hal ini mengingat jumlah hutangnya yang cukup banyak, sehingga jumlah bagian untuk gharim lebih banyak dibandingkan dengan asnaf yang lainnya. 
Hal ini dilakukan dengan tujuan agar terciptanya sebuah keadilan di lingkungan jamaah Masjid At-Taqwa Desa Pamedaran.

Dalam UU No. 23 Tahun 2011 Pasal 2 dijelaskan bahwa Pengelolaan zakat fitrah harus sesuai dengan asas Syari'at Islam, asas kemanfaatan, akuntabilitas dan ada kepastian hukum. ${ }^{22}$ Yang dimaksud sesuai dengan Syari'at Islam, jika melihat pendapat Imam Syafi'i yaitu zakat fitrah harus berupa makanan pokok penduduk setempat dan harus dibayarkan dengan estimasi waktu dari hari pertama masuknya bulan Ramadhan sampai tenggelamnya matahari 1 syawal. ${ }^{23}$ Adapun takarannya yaitu satu sha', hal ini disandarkan pada hadits Abu Sa'id Al Khudri, dia berkata:

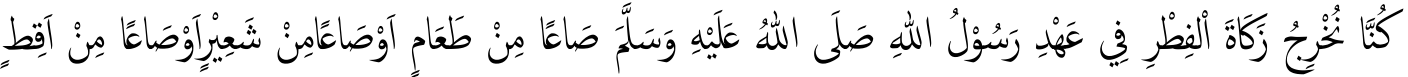

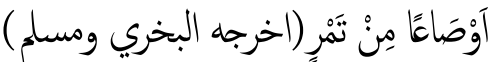

Artinya :" dimasa Rasulullah SAW, kami mengeluarkan Zakat Fitrah satu sha" makanan, atau satu sha" gandum, atau satu sha" keju, atau satu sha" kurma" ${ }^{24}$

Dalam memahami dan menghitung satu sha' Imam Malik, Imam Syafi'i dan Imam Ahmad bin Hambal berpendapat bahwa satu sha' setara dengan lima sepertiga rithl Irak. Lima sepertiga rithl Irak setara dengan 2176 gram atau 2,2 kilogram. dengan demikian, kadar zakat fitrah menurut kelompok ini adalah 2,2 kilogram. ${ }^{25}$ Selain itu, zakat fitrah yang terkumpul juga harus disalurkan kepada mustahiqnya dengan secara merata untuk masing-masing golongan penerimanya. ${ }^{26}$

Adapun pengelelolaan zakat fitrah yang dilakukan di Masjid At-Taqwa, jika melihat realita dalam pelaksanaannya belum sepenuhnya sesuai dengan syari'at Islam yang berdasarkan pada pendapat Imam Syafi'i, karena ketentuan-ketentuan yang ditetapkan oleh Imam Syafi'i belum dijalankan secara keseluruhan, yaitu dalam menentukan jumlah bagian zakat fitrah menurut pendapat Imam Syafi'i seharusnya

${ }^{22}$ Undang-Undang Republik Indonesia Nomor 23 Tahun 2011 Tentang Pengelolaan Zakat Pasal

2.

23 Gus Arifin, Dalil-Dalil Dan Keutamaan Zakat, Infaq, Sedekah, Jakarta: PT. Elex Media Komputindo, 2011. hlm. 148-149.

${ }^{24}$ Al Faqih Abdul Wahid Muhammad, Bidayatul Mujtahid, Jakarta: Pustaka Amani, 2007, hlm. 626

25 https://islam.nu.or.id/post/read/91590/beda-pendapat-ulama-soal-besaran-zakat-fitrahyang-harus-dikeluarkan. Diakses pada 5 juli 2021

${ }^{26}$ Syaikh Abdurrahman Al-Juzairi, Fikih Empat Madzhab, Jilid 2, Terjemah Shofa'u Qolbi Djabir dkk, Jakarta: Pustaka Al-Kautsar, 2020, hlm. 485. 
dibagikan secara merata terhadap masing-masing golongan, sedangkan dalam pelaksanaannya amil membagikan terhadap masing-masing golongan penerimanya dengan jumlah yang berbeda. Sedangkan yang dimaksud sesuai dengan asas kemanfaatan yaitu dengan adanya pemberian zakat fitrah kepada fakir miskin sehingga kebutuhan mereka pada hari Raya Idul Fitri bisa tercukupi, selain itu juga agar terhindar dari perbuatan meminta-minta.

Adapun yang dimaksud sesuai asas akuntabilitas adalah panitia zakat fitrah memiliki database nama-nama dan jumlah masyarakat yang membayarkan zakatnya di Masjid At-Taqwa serta jumlah zakat fitrah yang diperoleh, meskipun hal itu masih jauh dari kesempurnaan dan perlu perbaikan disetiap tahunnya. Untuk mengawal kesejahteraan masyarakat, setelah selesainya pendistribusian seharusnya melaporkaan kepada Badan Amil Zakat (BAZ) agar dapat dijadikan sebagai pertimbangan selanjutnya. Namun dalam hal ini para amil tidak melaporkan kepada Badan Amil Zakat (BAZ) yang ada di Kabupaten Brebes, karena selama ini masyarakat belum semuanya paham secara baik bagaimana pengelolaan zakat fitrah yang sesuai dengan undang-undang. Selain itu juga karena selama ini tidak adanya sosialisasi ataupun arahan dari Badan Amil Zakat (BAZ) yang ada di Kabupaten Brebes. Sehingga masyarakat sangat membutuhkan bimbingan dan arahan yang sifatnya kontinyu, dengan tujuan agar tercapainya asas keadilan dan pemerataan kesejahteraan. Jadi, pada bagian-bagian tertentu memang masih membutuhkan penyempurnaan.

Dikarenakan Indonesia Negara hukum, maka dalam pelaksanaan kegiatan sosial bermasyarakat dan bernegara harus sesuai dengan prinsip Negara berdasarkan peraturan undang-undang sebagai hukum positif guna menciptakan serta menjamin adanya kepastian hukum. ${ }^{27}$ Oleh karena itu, adanya undang-undang No 23 Tahun 2011 tentang pengelolaan zakat adalah bentuk perwujudan UndangUndang Syari'ah yang menjadi hukum positif sehingga suatu lembaga mendapat kepastian hukum dalam pengelolaannya. ${ }^{28}$ Berkaitan dengan hal pertanggungjawaban, dalam Peraturan Pemerintah Republik Indonesia Nomor 14 tahun 2014 bab VII bagian keempat pasal 66 ayat 1 dan 2 tentang pengelolaan

\footnotetext{
${ }^{27}$ Pasal 1 Ayat 3 UUD Negara Republik Indonesia Tahun 1945

28 Budi Rahmat Hakim, "Analisis Terhadap Undang-undang No. 23 Tahun 2011 Tentang Pengelolaan Zakat (Perspektif Hukum Islam)", Syari'ah Jurnal Ilmu Hukum, Volume 15, 2, 2015, hlm. 160.
} 
zakat telah dijelaskan pada ayat 1 bahwa "Dalam hal di suatu komunitas dan wilayah tertentu belum terjangkau oleh BAZNAS dan LAZ, kegiatan pengelolaan zakat dapat dilakukan oleh perkumpulan orang, perseorangan tokoh umat Islam (alim ulama), atau pengurus/takmir masjid/musholla sebagai amil zakat", ayat 2 berisi "kegiatan pengelolaan zakat oleh amil zakat sebagaimana dimaksud pada ayat 1 dilakukan dengan memberitahukan secara tertulis kepada Kepala Kantor Urusan Agama Kecamatan". ${ }^{29}$ Dengan adanya Peraturan Pemerintah diatas dapat dipahami bahwa badan pemerintah yang terakhir dalam bidang pengelolaan zakat adalah Kantor Urusan Agama dimana dalam hal ini sebatas menerima pemberitahuan tertulis dari amil zakat perseorangan, pengurus/takmir masjid atau perkumpulan orang dalam masyarakat. Jika pengurus/amil zakat tersebut tidak memberitahukan kepada Kepala Kantor Urusan Agama (KUA) Kecamatan maka amil zakat tersebut dapat dikenai sanksi administratif berupa penghentian dari kegiatan pengelolaan zakat dan teguran tertulis sebagaimana yang terdapat dalam Peraturan Pemerintah Republik Indonesia Nomor 14 Tahun 2014 bab X pasal 78 dan pasal $83 .{ }^{30}$

Zakat fitrah adalah kewajiban bagi setiap ummat Islam, yang mana di dalamnya tidak hanya sebatas urusan ibadah manusia kepada Allah sebagai Tuhannya, namun juga terdapat nilai-nilai kemanusiaan yang sifatnya saling tolong menolong sehingga dapat membuahkan kemanfaatan, baik secara moril ataupun materil bagi yang menerima (mustahiq) dan yang memberi zakat (muzakki). Sebagaiman hadits Rasulullah yang diriwayatkan oleh Abu Daud berikut:

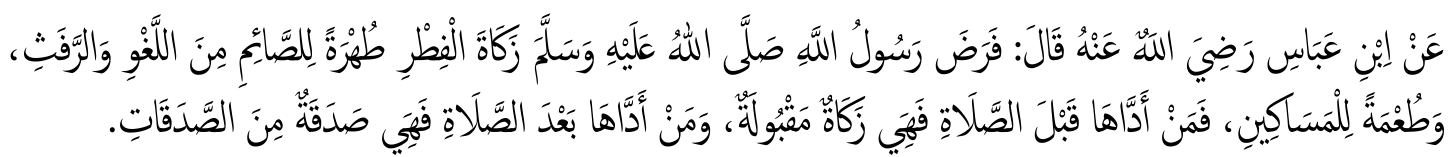

Artinya: "Dari Ibnu Abbas RA, ia berkata, Rasulullah SAW mewajibkan zakat fitrah untuk membersihkan orang yang berpuasa dari perkataan sia-sia dan perkataan kotor, dan sebagai makanan bagi orang-orang miskin. Barang siapa yang menunaikannya sebelum shalat (Idul Fitri), berarti ini merupakan zakat yang diterima, dan barang siapa yang menunaikannya setelah shalat (idul fitri) berati hal itu merupakan sedekah biasa". (Hr. Abu daud, ibnu Majah, dan Daru Quthni). ${ }^{31}$

\footnotetext{
${ }^{29}$ Peraturan Pemerintah No.14 Tahun 2014 bab VII pasal 66

30 Peraturan Pemerintah No.14 Tahun 2014 bab X pasal 78 dan 83

${ }^{31}$ Abu Dawud Sulaiman Bin Al-Asy'ats Al-Azdi As-Sijistani, Ensiklopedia Hadits 5; Sunan Abu Dawud, Terjemah. Muhammad Ghazali dkk, Jakarta: Almahira, Cet. 1, 2013, hlm. 334
} 
Dari hadits diatas dapat dipahami bahwa manfaat zakat fitrah dapat membersihkan sifat buruk yang terdapat dalam diri manusia, baik itu berupa perkataan yang kotor, iri, dengki, sombong ataupun yang lainnya. Dengan memberi zakat fitrah maka akan menimbulkan rasa kasih sayang sehingga fakir miskin yang diberi zakat fitrah pun akan merasa bahagia dan terhindar dari perbuatan memintaminta pada hari Raya Idul Fitri. Sebagaimana yang telah dijelaskan sebelumnya, pendistribusian zakat fitrah yang dilakukan oleh amil di Masjid At-Taqwa Desa Pamedaran yaitu dengan mendahulukan bagian fakir miskin, ketika semuanya sudah mendapat bagian, maka zakat fitrah yang tersisa diberikan kepada mustahiq yang lainnya. ${ }^{32}$ Abu Bakar Jabir Al-Jazairi telah mengemukakan pendapatnya yang dikutip dalam buku yang berjudul "Ensiklopedi Muslim", bahwa orang yang menerima zakat fitrah adalah sama seperti penerima zakat-zakat lainnya. Hanya saja orang-orang fakir dan miskin lebih diutamakan menerima zakat fitrah daripada penerimapenerima lainnya.

Adapun pendistribusian zakat fitrah yang dilakukan oleh amil di Masjid AtTaqwa Desa Pamedaran, mereka membagikan zakat fitrahnya dengan mengutamakan fakir miskin terlebih dahulu, disamping itu dalam menentukan jumlah bagiannya pun mereka menyesuaikan kebutuhan masing-masing jiwa, sehingga bagian orang fakir lebih banyak daripada orang miskin, karena kedudukan orang fakir secara ekonomi lebih rendah daripada orang miskin. Menurut jumhur ulama, bahwa orang fakir adalah orang-orang yang tidak mempunyai harta atau penghasilan layak untuk memenuhi kebutuhan sandang, pangan, tempat tinggal, dan segala keperluan pokok lainnya, baik untuk dirinya sendiri maupun untuk keluarga dan orang-orang yang menjadi tanggungannya. ${ }^{33}$ Sedangkan orang miskin adalah orang yang mempunyai harta atau penghasilan layak untuk memenuhi kebutuhan diri dan tanggungannya, tetapi penghasilan tersebut tidak mencukupi. ${ }^{34}$

Setelah fakir miskin semuanya mendapat bagian, lalu amil membagikannya kepada golongan fisabilillah, dan amil mengambil bagiannya disesuaikan dengan

\footnotetext{
${ }^{32}$ Abu Bakar Jabir Al-Jazairi, Ensiklopedi Muslim, Jakarta: Darul Fala, 2015. hlm. 484

33 Andi Suryadi, Mustahiq Dan Harta Yang Wajib Dizakati Menurut Kajian Para Ulama, Jurnal Keislaman, Kemasyarakatan \& Kebudayaan, Program Pascasarjana Uin Sultan Maulana Hasanuddin Banten, Volume 19, (1), 2018, hlm. 3.

34 Ibid,
} 
upah kerja satu hari, kemudian sisanya diberikan kepada gharim seluruhnya, berdasarkan alasan bahwa mengingat semua fakir miskin, fisabilillah serta amil juga sudah mendapat bagiannya masing-masing, sehingga sisa beras zakat fitrah seluruhnya diberikan kepada gharim. Pemberian zakat fitrah terhadap gharim tersebut adalah bertujuan untuk memberikan dukungan dalam kebaikan karena telah melakukan suatu perbuatan yang sangat terpuji, juga demi terwujudnya kemaslahatan umat.

Adapun kriteria gharim yang berhak menerima zakat menurut Yusuf AlQardhawi yaitu ada dua macam: ${ }^{35}$ a.) Orang yang mempunyai hutang untuk kepentingannya sendiri, seperti untuk memberi nafkah, membeli pakaian, menjalankan pernikahan, mengobati orang sakit, menikahkan anak, membangun rumah, atau menggantiakan barang orang lain yang rusak. Termasuk kriteria gharim disini yaitu mereka yang tertimpa bencana secara tiba-tiba seperti kebakaran, banjir, gempa bumi ataupun yang lainnya. Baik itu terjadi pada dirinya sendiri ataupun pada hartanya sehingga ia meminjam bagi dirinya dan keluarganya dikarenakan mempunyai kebutuhan yang mendesak; b.) Orang yang memiliki nilai-nilai kemanusiaan dan keluhuran yang tinggi, atau cita-cita luhur yang dikenal luas dalam masyarakat arab dan Islam. Misanya, orang yang mempunyai hutang karena mendamaikan dua golongan yang bersengketa dalam rebutan harta dan dengan sukarela ia menggantikan harta yang dipersengketakan agar tidak menimbulkan kemadharatan, orang yang melakukan kegiatan sosial yang bermanfaat seperti membangun panti asuhan, membangun rumah sakit, membangun masjid untuk ibadah shalat ataupun perbuatan baik lainnya yang ditujukan untuk melayani kepentingan masyarakat. Sesungguhnya orang tersebut telah berkhidmat didalam kebajikan untuk kepentingan masyarakat. Arti semua ini adalah bahwa seseorang yang mempunyai hutang karena untuk melayani kepentingan masyarakat, meskipun dia orang kaya hendaknya diberi bagian zakat untuk membayar hutangnya.

Dalam hal ini, kategori gharim yang diberi bagian zakat fitrah oleh amil di Desa Pamedaran, jika melihat pendapat Yusuf Al-Qardhawy di atas sebenernya kurang tepat karena pemilik hutang yang sesungguhnya adalah lembaga/masjid, ia hanya sebatas perantara dalam hutang tersebut dan yang berkewajiban membayar

${ }^{35}$ Didin Hafidhuddin, Hukum Zakat, Terj. Jakarta: PT .Pustaka Mizan, 1999, hlm. 604

Received: 2021-11-19 Accepted: 2021-12-21 Published: 2021-12-23 
hutangnya adalah lembaga/masjid tersebut. Sehingga apabila ia diberi bagian zakat fitrah dengan alasan sebagai gharim itu tidak berhak menerimanya, karena pemilik hutang yang sesungguhnya bukan pribadinya, tapi itu merupakan hutang lembaga/masjid. Kecuali hutang pembangunan masjid itu merupakan hutang pribadinya, dalam artian dia yang bertanggungjawab membayar atas hutang tersebut, maka ia bisa dikategorikan sebagai gharim dan berhak menerima bagian zakat fitrah. Akan tetapi, jika orang tersebut dikategorikan sebagai fisabilillah justru itu lebih tepat dan ia berhak menerima bagian zakat fitrah, karena ia telah melakukan perbuatan yang sifatnya ibadah di jalan Allah yaitu berkiprah mengurusi dalam pembangunan masjid demi tegaknya syiar Islam.

Sebagaimana yang dimaksud sabilillah dalam Al-Qur'an Surat At-Taubah Ayat 60 menurut al-Kasani dalam al-Badaa'ii' menafsirkan bahwa sabilillah (jalan Allah) yang dimaksud dalam ayat tersebut adalah semua macam ibadah. Dengan demikian mencakup semua orang yang berusaha di jalan Allah dan kebaikan, jika dia membutuhkan. Karena, "sabilillah" adalah umum dalam kepemilikan, yaitu mencakup pembangunan masjid dan semisalnya, seperti yang telah disebutkan. Sebagaimana ulama Hanafiyah menafsirkan kalimat "sabilillah" dengan mencari ilmu, sekalipun orang yang mencari ilmu tersebut kaya. ${ }^{36}$

\section{Simpulan}

Berdasarkan uraian di atas, penelitian yang dilakukan di Desa Pamedaran Kecamatan Ketanggungan Kabupaten Brebes tentang praktik pengelolaan zakat fitrah, maka dapat diambil kesimpulan bahwa Pengelolaan zakat fitrah di Masjid AtTaqwa diawali dengan perencanaan melalui musyawarah para tokoh dan amil pada $\mathrm{H}-3$ idul fitri dan dilaksanakan pada $\mathrm{H}-1$ idul fitri dengan waktu pengumpulan zakat fitrah dari setelah sholat subuh sampai menjelang sholat ashar, lalu amil menghitung jumlah zakat fitrah yang sudah terkumpul, kemudian didistribusikan kepada asnaf yang ada di lingkungan masjid At-Taqwa yaitu asnaf fakir, miskin, amil, fisabilillah dan gharim. Dalam menentukan jumlah bagiannya dengan menyesuaikan kebutuhan masing-masing jiwa, sehingga bagian orang fakir lebih banyak daripada orang miskin, karena kedudukan orang fakir secara ekonomi lebih rendah daripada

${ }^{36}$ Wahbah Az-Zuhaili, Fiqih Islam Wa Adillatuhu, Jilid 3, Terjemah Abdul Hayyi Al-Kattani dkk, Jakarta: Gema Insani, 2011, hlm. 287-288. 
orang miskin. lalu amil membagikannya kepada golongan fisabilillah disamakan dengan golongan miskin, dan amil mengambil bagiannya disesuaikan dengan upah kerja satu hari, kemudian sisanya diberikan kepada gharim seluruhnya.

Pendistribusian zakat fitrah yang dilakukan oleh Takmir Masjid At-Taqwa Desa Pamedaran terhadap gharim yang hutangnya untuk lembaga tidak sesuai dengan hukum Islam, karena yang dimaksud gharim menurut empat madzhab ataupun menurut Yusuf Al-Qardhawy adalah orang yang berhutang dan menjadi kewajiban bagi dirinya untuk membayar hutang tersebut, sedangkan dalam hal ini, orang yang dianggap sebagai gharim hanya sebatas perantara atas hutang itu dan pemilik hutang yang sesungguhnya adalah lembaga/masjid tersebut. Dirinya juga bukan sebagai orang yang wajib membayarnya sehingga tidak boleh diberi bagian zakat fitrah atas dasar sebagai asnaf gharim. 


\section{DAFTAR PUSTAKA}

Ahmad, Shofian, Amir Husin Mohd. Nor, Zakat Membangun Ummah, Kuala Lumpur: Sanon Printing Corporation SDN BHD, 2002.

Page | 162

Al-Jazairi, Abu Bakar Jabir, Ensiklopedi Muslim, Jakarta: Darul Fala, 2015.

Al-Juzairi, Syaikh Abdurrahman, Fikih Empat Madzhab, Jilid 2, Terjemah Shofa'u Qolbi Djabir dkk, Jakarta: Pustaka Al-Kautsar, 2020.

Al-Zuhayly, Wahbah, Zakat Kajian Berbagai Mazhab, Agus Effendi, Bahrudin Fananny (Penterjemah), Bandung: PT. Remaja Rosdakarya Offset, 2008.

Anwar, Moch, dkk, Fathul Mu'in, (Terjemah), Bandung: Sinar Baru Agensindo, 1994.

Arifin, Gus, Dalil-Dalil Dan Keutamaan Zakat, Infaq, Sedekah, Jakarta: PT. Elex Media Komputindo, 2011.

Az-Zuhaili, Wahbah, Fiqih Islam Wa Adillatuhu, Jilid 3, Terjemah Abdul Hayyi AlKattani dkk, Jakarta: Gema Insani, 2011.

Badruddin, Amil Zakat Fitrah, wawancara, pada 10 agustus 2020. Jam 17:00 WIB

Barkah, Qodariah, Peny Cahaya Azwari, Saprida, Zuul Fitriani Umari, Fikih Zakat, Sedekah, dan Wakaf, Jakarta: Prenadamedia Group, 2020.

Hafidhuddin, Didin, Hukum Zakat, Terj. Jakarta: PT .Pustaka Mizan, 1999.

Hakim, Budi Rahmat, "Analisis Terhadap Undang-undang N0. 23 Tahun 2011 Tentang Pengelolaan Zakat (Perspektif Hukum Islam)", Syari'ah Jurnal Ilmu Hukum, Volume 15, 2, 2015.

Hakim, M. Fikril, Abu Sholahuddin (Penterjemah), Fiqh Populer Terjemah Fathul Mu'in, Kediri: Lirboyo Press.

Harahap, Khairul Amru dan Masrukhin, Fikih Sunnah, (Terjemah), Jakarta: Cakrawala Publishing, 2015.

Hasbi, Al-Furqon, 125 Masalah Zakat, Solo: Tiga Serangkai, 2008. 
https://islam.nu.or.id/post/read/91590/beda-pendapat-ulama-soal-besaran-zakatfitrah-yang-harus-dikeluarkan. Diakses pada 5 juli 2021

Ismail, Ahmad Satori, Fikih Zakat Kontekstual Indonesia, Jakarta: Badan Amil Zakat Nasional, 2018.

Julkipli, Putra, Pelaksanaan Distribusi Zakat Fitrah Di Kelurahan Bintuju Kecamatan Batang Angkola Kabupaten Tapanuli Selatan, (Skripsi), Padangsidimpuan: Jurusan Ahwal Al-Syakhsiyyah Fakultas Syariah Dan Ilmu Hukum Institut Agama Islam Negeri Padangsidimpuan, 2018.

Kementerian Agama RI, Al-Qur"An...,

Muhammad, Abdul Wahid, Al Faqih, Bidayatul Mujtahid, Jakarta: Pustaka Amani, 2007.

Nasution, Lahmudin, Fiqih, Jakarta: Logos, 2015.

Pasal 1 Ayat 3 UUD Negara Republik Indonesia Tahun 1945.

Peraturan Pemerintah No.14 Tahun 2014 bab VII pasal 66

Peraturan Pemerintah No.14 Tahun 2014 bab X pasal 78 dan 83

Sulaiman , Abu Dawud Bin Al-Asy'ats Al-Azdi As-Sijistani, Ensiklopedia Hadits 5; Sunan Abu Dawud, Terjemah. Muhammad Ghazali dkk, Jakarta: Almahira, Cet. 1, 2013.

Suryadi, Andi, Mustahiq dan Harta Yang Wajib Dizakati Menurut Kajian Para Ulama, Jurnal Keislaman, Kemasyarakatan \& Kebudayaan, Program Pascasarjana Uin Sultan Maulana Hasanuddin Banten, Volume 19, (1), 2018.

Taslim, Anshari, Fikih Imam Syafi'i, Puasa dan Zakat, (Terjemah), Jakarta: Pustaka Azzam, 2003.

Undang-Undang Republik Indonesia Nomor 23 Tahun 2011 Tentang Pengelolaan Zakat Pasal 2. 
Undang-Undang Republik Indonesia Nomor 23 Tahun 2011 Tentang Pengelolaan Zakat. Pasal 1

Zabir, Muzakkir, Manajemen Pendistribusian Zakat Melalui Program Unggulan

Page | 164 Beasiswa Oleh Baitul Mal Aceh, Jurnal Manajemen dan Administrasi Islam, AlIdarah, Vol.1, No.1, Januari 2017.

Zuhri, M, dkk, Fiqih Empat Madzhab, Semarang: Asy-Syifa, 1994, Jilid 4. 